\title{
Stress in Medical Students in a Problem-Based Learning Curriculum
}

\author{
Ahmad Dagistani ${ }^{1}$, Fawwaz Al Hejaili ${ }^{2}$, Salih Binsalih ${ }^{1}$, Hamdan Al Jahdali ${ }^{1}$ \& Abdulla Al Sayyari ${ }^{1}$ \\ ${ }^{1}$ King Saud Bin Abdulaziz University for Health Sciences, Riyadh \\ ${ }^{2}$, Consultant, Al Mahjar Primary Health Care, Jeddah
}

Received: April 16, 2016

Accepted: April 27, 2016

Online Published: April 28, 2016

doi:10.5430/ijhe.v5n3p12

URL: http://dx.doi.org/10.5430/ijhe.v5n3p12

\section{Abstract \\ Background}

This study aims to assess stress level and its drivers among medical students using a PBL teaching system

\section{Method}

Higher Education Stress Inventory (HESI,) was used to assess stress among medical students. . All students in the College of Medicine were enrolled.

\section{Results:}

The response rate was $99 \%$. The prevalence of stress was $54.7 \%$. The overall mean stress score was higher in the $4^{\text {th }}$ year students (2.64) than $1^{\text {st }}$ year students $(2.52)(\mathrm{p}=0.01)$.

Junior students were more likely to be stressed by lack of clarity of the aims of the study $(\mathrm{p}=0.014)$ and lack of feedback from the teachers $(\mathrm{p}=0.003)$. Senior students were more likely to be stressed by lack of time for other activities $(\mathrm{p}=0.036)$, financial worries $(\mathrm{p}=0.027)$ ) and about preparedness for future profession $(\mathrm{p}=0.007)$

Despite the high stress scores, only $8.3 \%$ regretted their choice of career and $9.3 \%$ felt that they are not prepared well for their future profession

\section{Conclusions}

High level of stress was noted especially among senior students. Stress in junior students was more likely to be medical training-related and to be personal problems-related in senior students. The vast majority of students were happy with their choice of profession and optimistic about their future

Keywords: Stress, Medical students, PBL

\section{Introduction}

Medical school training requirements can be stressful to many medical students. There is a growing concern about stress and depression in medical students and its effect proper and optimal graduate output Depression is described as more common in medical students than in the general population (Compton, Conway, Stinson, Grant, 2006);Dahlin, Joneborg, \& Runeson, 2005 ; Firth, 1986; Bacchi \& Licinio, 2016; Tyssen, Vaglum, Grønvold, \& Ekeberg, 2005) The prevalence of depression the USA general population is $10 \%$ in the age group 18 to 29 years and $7 \%$ in the age group 30 to 44 years. (Compton et al., 2006) The prevalence of depression in UK general population has been reported to be $5 \%$ (Kumar \& Clark, 2002). In Saudi Arabia, the prevalence rate of depression in patients aged 15-29 years, is 23.2\%, and in those age group 30 to 44 years, is $17.8 \%$, whereas, in patients aged $45-65$ years the prevalence is $7.1 \% .3$ (Al-Khathami \& Ogbeide, 2002).

On the other hand, the prevalence of stress and depression among medical students was found to be higher than in the general population. In three British universities, the prevalence of stress among medical students was found to be $31.2 \%$. (Firth, 1986) In one study of medical students in Sweden, the prevalence of depression was $12.9 \%$.(Dahlin et al., 2005) A study in Saudi Arabia has shown that the prevalence of stress was present in 57\% of students with $19.6 \%$ having severe stress(Abdulghani, AlKanhal, Mahmoud, Ponnamperuma, \& Alfaris, 2011).

Students are often reluctant to seek help for stress and emotional problems (Tyssen et al., 2005) which can only be magnified leading to burnout occurring early in their careers (Guthrie et al., 1998)

Problem-based learning curriculum is a new experience in Saudi Arabia. The College of Medicine at the King Saud Bin Abdulaziz University for Health Science had adopted a problem based strategy as a method of teaching Medicine. The program consists of four year professional program for bachelor degree holders in Applied Medical fields. The 
program is based on the curriculum developed by the University of Sydney, Australia. The College of Medicine is integrated within King Abdulaziz Medical City (KAMC) in Riyadh which is a 1000-bed tertiary-care hospital that serves as the primary teaching center for medical students in the clinical phase of the training.("King Saud bin Abdulaziz University For Health Sciences," n.d.)

Using a validated tool to measure stress level among medical students, this study was carried out with the objective of determining the prevalence of self-perceived stress among medical students in a problem based learning curriculum.

\section{Methods}

\subsection{Instrument Used}

To assess the stress levels, we used the instrument Higher Education Stress Inventory (HESI) developed by Dahlin et al specifically to assess stress among medical students. It is neutral to educational program. (Dahlin et al., 2005)

The instrument contains 33 statements (Appendix-1) designed to assess degree of stress and its generators. The responses are rated on a four-point

Likert scale (i.e. 1-4), "1=totally disagree", $2=$ somewhat disagree", $3=$ somewhat agree, $4=$ totally agree; with reversed order for items describing absence of stressors. High scores are always less favorable.

As we do not have female medical students at King Saud bin Abdulaziz University for Health Sciences and since our medical students are of the same ethnic stock we dropped two items from HESI namely the statements. "I feel that I am less well treated because of my sex" and "I feel that I am less well treated because of my ethnic group". We added two new statements namely "the requirement of doing research is a source of worry for me" and "the requirement of doing frequent presentations is a source of worry for me" respectively. The instruments was initially tested in a pilot study in 20 students and reliability and validity assured.

\subsection{Study Sample}

All the four-year undergraduate students in the College of Medicine were enrolled in the study. The students were asked to complete the Higher Education Stress Inventory self-administered English version questionnaires during the academic year 2008-2009. Questionnaire were completed at least 2 weeks before or after an examination in order to minimize the extra examination-related stress. All students who participated in the study were informed about the purpose of the study and information regarding the instrument was explained. The participation was entirely on voluntary basis. All students were guaranteed complete confidentiality.

\subsection{Analysis}

Responses for each of the 33 statements were meant and compared to each other and according to the year of training. In addition the responses were analyzed after being dichotomized into "agree" (score $3 \& 4$ ) and "disagree" (scores 1 and 2). The 3 statements were further grouped into 7 stress generator areas. These are :worries about future endurancelcapacity(3 statements ), Non-supportive climate(4 statements), Faculty shortcoming(7 statements), Workload(4 statements), Insufficient feedback(2 statements), Low commitment(2 statements), and Financial concerns(2 statements) (Table-1).. (Appendix 2)

Statistical Analysis: Data were entered in and analyzed using SPSS version 17.0 . Student's t-test for independent samples was used to compare the mean values of study variables in relation to stress. The means of categorical data was compared using chi square A p-value of $<0.05$ was considered statistically significant.

\subsection{Results}

There were 108 responses from a total student population of 109 (a response rate of 99\%). The overall prevalence rate of stress was found to be $54.7 \%$.( $\mathrm{p}=0.05)$. One out of the seven factors, namely workload, was statistically significantly different when comparing $2^{\text {nd }}$ year to the other years $(\mathrm{p}=0.01)$.

The overall mean stress level was higher in the $4^{\text {th }}$ year students $(2.64)$ compared to $1^{\text {st }}$ year students $(2.52)(\mathrm{p}=0.01)$. One out of the 7 "stressors" namely "workload," was statistically significantly more stressing for senior students than for junior students different when comparing junior and senior years $(\mathrm{p}=0.01)$. There was also a tendency- not reaching significant level-towards worsening stress scores in 3 stress factors as the year of study progresses. These are "worries about future endurance capacity (from 2.88 to 3.15), "non-supportive climate" (from 2.63 to 2.85)., and "financial concerns" ( from 3.02 to 3.46). (Table 1)

Nevertheless junior students showed higher stress scores than senior students $\mathrm{n} 5$ of the 33 statements tested namely including "the teachers often fail to clarify the aims of the studies" and "the teachers do not often give feedback on the students' knowledge and skills" ( $\mathrm{p}=0.003)$. 
When analyzing the data in a dichotomous fashion (agree versus disagree) we find significant differences in the responses by $1^{\text {st }}$ and $4^{\text {th }}$ year students in seven out of the total 33 statements tested Higher percentage of junior students agreed that stress was seen in the areas of "the teachers often fail to clarify the aims of the studies" ( $78.6 \%$ Vs. $56.1 \%$, $\mathrm{p}=0.0 .014)$ and "the teachers do not often give feedback on the students' knowledge and skills" $(64.3 \%$ Vs. $34.8 \%$, $\mathrm{p}=0.003$ ), One the other hand, more senior medical students expressed stress in 4 statements namely ““"studies control my life and I have little time for other activities" $(90.9 \%$ Vs. $76.20 \%, \mathrm{p}=0.036)$ and "I feel that the training is not preparing me well for my future profession" ( $97 \%$ Vs. $81 \%, p=0.007)$, "the requirement for frequent presentations is a source of worry for me ( $66.7 \%$ Vs. $42.9 \%$ p-0.013) and "I am worried about my future financial status" ( $78.8 \%$ Vs. $59.9 \%$ p-0.027) (Table-2)

Despite the high scores indicating stress that still only a very small minority of the students felt that "the studies do not stimulate their personal development" (13.9\%), that "they are not satisfied with their choice of career".(8.3\%), that "they are not proud of their future profession" ( $5.6 \%)$ or that "they feel that the training is not preparing them well for their future profession ( $9.3 \%$ ) (Table 3)

Table 1. Means of stress-generating factors according to educational year

\begin{tabular}{llllll}
\hline & \multicolumn{7}{c}{ 1st year2d year3rd year4th yearp-value } \\
\hline Worries about future endurance capacity & 2.88 & 2.92 & 2.94 & 3.15 & 0.35 \\
Non-supportive Climate & 2.63 & 2.65 & 2.69 & 2.84 & 0.29 \\
Faculty Shortcomings & 2.15 & 2.34 & 2.20 & 2.20 & 0.31 \\
Workload & 3.27 & 2.83 & 3.05 & 3.20 & 0.01 \\
Insufficient feedback & 2.39 & 2.58 & 2.23 & 2.34 & 0.29 \\
Low Commitments & 1.30 & 1.38 & 1.59 & 1.32 & 0.29 \\
Financial Concerns & 3.02 & 3.06 & 3.20 & 3.46 & 0.10
\end{tabular}

Table 2. Percent of junior and senior students agreeing with the statements shown (only scores with significant differences are shown

\begin{tabular}{|c|c|c|c|}
\hline & Junior students & senior students & p-value \\
\hline Studies control my life and i have little time for other activities & 76.20 & 90.9 & 0.036 \\
\hline The teachers often fail to clarify the aims of the studies & 78.60 & 56.1 & 0.014 \\
\hline $\begin{array}{l}\text { The requirement for frequent presentations is a source of worry } \\
\text { for me }\end{array}$ & 42.9 & 66.7 & 0.013 \\
\hline $\begin{array}{l}\text { I feel that the training is not preparing me well for my future } \\
\text { profession }\end{array}$ & 81 & 97 & 0.007 \\
\hline I am worried about my future financial status & 59.9 & 78.8 & 0.027 \\
\hline $\begin{array}{l}\text { The teachers do not often give feedback on the students' } \\
\text { knowledge and skills }\end{array}$ & 64.3 & 34.8 & 0.003 \\
\hline
\end{tabular}

Table 3. Very few students show evidence of lack of commitment

\begin{tabular}{ll}
\hline & Agree \\
\hline The studies do not stimulate my personal development & $13.90 \%$ \\
I am not satisfied with my choice of career. & $8.30 \%$ \\
I am not proud of my future profession & $5.60 \%$ \\
I feel that the training is not preparing me well for my future profession & $9.30 \%$ \\
\hline
\end{tabular}

\section{Discussion}

A wide range of different measures have been used to screen for depression and stress among medical students. Depression has been assessed with different tools like Beck's Depression Inventory (Sherina, Rampal, \& Kaneson, 2004), General Health Questionnaire, Kessler Psychological Distress Inventory and other common and less common instruments. (Firth 1986; Sherina et al., 2004; Styles, 1993; Singh, Hankins, \& Weinman, 2004; Tyssen et al., 2005) 
Depression is prevalent in $\mathrm{n} 12 \%$ of medical students with higher prevalence among preclinical students and in home staying ( as opposed to hostel staying) students (Cuttilan, Sayampanathan, \& Ho, 2016).

The instrument Higher Education Stress Inventory (HESI) which has been developed Dahlin and colleagues (Dahlin et al., 2005)specifically to serve the purpose of assessing stress in medical students was used. Based on the Perceived Medical School Stress Scale, (PMSS) (Peter P. Vitaliano, Maiuro, Mitchell, \& Russo, 1989), HESI is a more comprehensive. It has also been used in other higher educational settings besides medical schools, which allows for comparative studies We have had a good response rate to our survey of $99 \%$, which provides an adequate sample size to fulfill the objectives of this study. The results of this study showed that medical students had a high prevalence of stress. Overall the prevalence of stress in this study is $54.7 \%$, which is similar to the study done at King Saud University in Riyadh (Abdulghani et al., 2011)but higher than a study done on British medical students of 31.2\%.(Firth, 1986).

The overall mean stress level was higher in the $4^{\text {th }}$ year students $(2.64)$ compared to $1^{\text {st }}$ year students $(2.52)(\mathrm{p}=0.01)$. The increase in stress in our senior students was expected as it is the clinical teaching where students are loaded with clinical schedules at the hospitals.(Abdulghani et al., 2011)(Fares, Al Tabosh, Saadeddin, El Mouhayyar, \& Aridi, 2016)

This is in agreement with other studies whish report that the level of stress increases as the student progress in medical school (Dahlin et al., 2005; Niemi \& Vainiomäki, 2006)Other studies have also reported that mental health worsens after students are admitted to medical school and remains poor throughout the training(Dyrbye, Thomas, \& Shanafelt, 2005) especially in the transition from basic science teaching to clinical training. (Helmers, Danoff, Steinert, Leyton, \& Young, 1997). There are, however other studies where the level of stress was found to decrease as the students' progress in medical school, especially after the basic sciences years. (Abdulghani et al., 2011) (Dahlin et al., 2005) In one report, it was found that distress is more common among female medical student (Bore, Kelly, \& Nair, 2016).

The stressors were different in junior when compared to senior medical students More junior than senior students were stressed by lack of clarity of the aims of the study $(\mathrm{p}=0.014)$ and lack of feedback from the teachers $(\mathrm{p}=0.003)$. On the other hand, more senior than junior students were stressed because of lack of time for other activities $(\mathrm{p}=0.036)$, financial worries $(\mathrm{p}=0.027))$ and worries about preparedness for future profession $(\mathrm{p}=0.007)$

Resiliency skills building exercise. may be useful in reducing stress among medical students (Wald, Haramati, Bachner, \& Urkin, 2016) (Bore et al., 2016)

Nevertheless, despite the high scores indicating stress that still only a very small minority of the students felt that "the studies do not stimulate their personal development" $(13.9 \%)$, that "they are not satisfied with their choice of career". $(8.3 \%)$, that "they are not proud of their future profession" $(5.6 \%)$ or that "they feel that the training is not preparing them well for their future profession (9.3\%)

The negative effects of long and tiring medical education on the psychological status of students might explain the increased prevalence of stress and depression among medical students. A British study showed that one third of psychiatrically ill students did not graduate from the college. (Salmons, 1983). Beside educational obligations, social factors are reasons for psychological disturbance in students. Financial worries might be attributed to the comparison of students to their peers in other disciplines. Worrisome thinking has been suggested to act not only as a stressor by itself, but also as a mediating the effect of psychosocial stressors.(Borschos, Kühlhorn, \& Rydberg, 1999)

The data in this study suggest that special care must be taken in senior medical students, who have higher level of stress. Setting up a student support system might contribute in easing the higher level of stress along the study course and especially in the third and fourth year of study. Preventive strategies targeted at the students must be implemented in order to prevent the development of more serious conditions. Psychiatric disorders were the most common cause of premature retirement among UK doctors. (Abramovitch, Schreier, \& Koren, 2000) The effect of stress in medical students and the development of a burnout syndrome had been shown in one study.(Dahlin et al., 2005)

Wellness and mental health programmes are needed to help students to make an appropriate transition between different learning environments with changing learning demands. Medical schools in the United States and Canada have initiated health promotion programmes and have reported positive results in reducing the negative effects of stress upon medical students' health and academic performance. (Abramovitch, Schreier, and Koren 2000; Lee \& Graham, 2001; Wolf, Randall, \& Faucett, 1988)

Students must be taught and encouraged to look for any cardinal signs and symptoms of stress and depression such as recent weight changes, sleeping disturbances, concentration difficulties, increasing cigarette smoking and so on so forth. The problem with help-seeking is perceived as a problem among medical students. \{Citation\} In one study, 
$17.3 \%$ of students had consulted a professional because of a mental problem at some time since they started medical school(Dahlin et al., 2005)

Studies have shown that whereas the sources of stress in medical students are generally related to personal problems (academic pressures, social/personal issues, and financial problems), (P. P. Vitaliano, Russo, Carr, \& Heerwagen, 1984) .the principal stressors in PBL were related to medical training (in particular, uncertainty -bout study behaviour, progress and aptitude) rather than personal problems(Moffat, McConnachie, Ross, \& Morrison, 2004). It is interesting that in our PBL-trained students, more juniors were indeed stressed by medical training-related aspects whereas more senior students were stressed by personal problems.

Another study showed that compared to medical students taught by traditional methods, the PBL students were more likely to feel that they did not know what the faculty expected of them, complain about an unclear curriculum and that there was a lack of opportunity to explore academic subjects of interest ( Lewis, A. D., Menezes, D. A. B., McDermott, H. E., Hibbert, L. J., Brennan, S.-L., Ross, E. E., \& Jones, L. A. (2009). 2009). This finding is similar to our findings among junior students where stress factors included by lack of clarity of the aims of the study and lack of feedback from the teachers

\section{Conclusions}

The study suggests that higher level of stress among medical students which is noted to be higher in senior students. More junior students had stress due to medical training-related aspects whereas more senior students were stressed by personal problems.

The vast majority of students were happy with their choice of profession and optimistic about their future.

\section{References}

Abdulghani, H. M., AlKanhal, A. A., Mahmoud, E. S., Ponnamperuma, G. G., \& Alfaris, E. A. (2011). Stress and its effects on medical students: a cross-sectional study at a college of medicine in Saudi Arabia. Journal of Health, Population and Nutrition, 516-522. http://dx.doi.org/10.3329/jhpn.v29i5.8906

Abramovitch, H., Schreier, A., \& Koren, N. (2000). American medical students in Israel: stress and coping-a follow-up study. Medical Education, 34(11), 890-896. http://dx.doi.org/10.1046/j.1365-2923.2000.00677.x

Al-Khathami, A. D., \& Ogbeide, D. O. (2002). Prevalence of mental illness among Saudi adult primary-care patients in Central Saudi Arabia. Saudi Medical Journal, 23(6), 721-724.

Bacchi, S., \& Licinio, J. (2016). Resilience and Psychological Distress in Psychology and Medical Students. Academic Psychiatry: The Journal of the American Association of Directors of Psychiatric Residency Training and the Association for Academic Psychiatry. http://dx.doi.org/10.1007/s40596-016-0488-0

Bore, M., Kelly, B., \& Nair, B. (2016). Potential predictors of psychological distress and well-being in medical students: a cross-sectional pilot study. Advances in Medical Education and Practice, 7, 125-135. http://doi.org/10.2147/AMEP.S96802

Borschos, B., Kühlhorn, E., \& Rydberg, U. (1999). [Alcohol and drug use among medical students 1995: more than every tenth male student had hazardous alcohol drinking habits]. Lakartidningen, 96(28-29), 3253-3258.

Compton, W. M., Conway, K. P., Stinson, F. S., Grant, B. F., \& others. (2006). Changes in the prevalence of major depression and comorbid substance use disorders in the United States between 1991-1992 and 2001-2002. American Journal of Psychiatry. http://dx.doi.org/10.1176/ajp.2006.163.12.2141

Cuttilan, A. N., Sayampanathan, A. A., \& Ho, R. C.-M. (2016). Mental health issues amongst medical students in Asia: a systematic review [2000-2015]. Annals of Translational Medicine, 4(4), 72. http://doi.org/10.3978/j.issn.2305-5839.2016.02.07

Dahlin, M., Joneborg, N., \& Runeson, B. (2005). Stress and depression among medical students: A cross-sectional study. Medical Education, 39(6), 594-604. http://dx.doi.org/10.1111/j.1365-2929.2005.02176.x

Dyrbye, L. N., Thomas, M. R., \& Shanafelt, T. D. (2005). Medical student distress: causes, consequences, and proposed solutions. In Mayo Clinic Proceedings (Vol. 80, pp. 1613-1622). Elsevier. http://dx.doi.org/10.4065/80.12.1613

Fares, J., Al Tabosh, H., Saadeddin, Z., El Mouhayyar, C., \& Aridi, H. (2016). Stress, Burnout and Coping Strategies in Preclinical Medical Students. North American Journal of Medical Sciences, 8(2), 75-81. http://doi.org/10.4103/1947-2714.177299 
Firth, J. (1986). Levels and sources of stress in medical students. Br Med J (Clin Res Ed), 292(6529), 1177-1180. http://dx.doi.org/10.1136/bmj.292.6529.1177

Guthrie, E., Campbell, M., Black, D., Creed, F., Bagalkote, H., \& Shaw, C. (1998). Psychological stress and burnout in medical students: a five-year prospective longitudinal study. Journal of the Royal Society of Medicine, 91(5), 237-243.

Helmers, K. F., Danoff, D., Steinert, Y., Leyton, M., \& Young, S. N. (1997). Stress and depressed mood in medical students, law students, and graduate students at McGill University. Academic Medicine, 72(8), 708-14. http://dx.doi.org/10.1097/00001888-199708000-00018

King Saud bin Abdulaziz University For Health Sciences. (n.d.). Retrieved April 16, 2016, from http://www.ksau-hs.edu.sa/English/Pages/default.aspx

Kumar, P. J., \& Clark, M. (2002). Textbook of clinical medicine. Pub: Saunders (London), 1099-1121.

Lee, J., \& Graham, A. V. (2001). Students' perception of medical school stress and their evaluation of a wellness elective. Medical Education, 35(7), 652-659. http://dx.doi.org/10.1046/j.1365-2923.2001.00956.x

Lewis, A. D., Menezes, D. A. B., McDermott, H. E., Hibbert, L. J., Brennan, S.-L., Ross, E. E., \& Jones, L. A. (2009). A comparison of course-related stressors in undergraduate problem-based learning (PBL) versus non-PBL medical programmes. BMC Medical Education, 9, 60. http://dx.doi.org/10.1186/1472-6920-9-60

Moffat, K. J., McConnachie, A., Ross, S., \& Morrison, J. M. (2004). First year medical student stress and coping in a problem-based learning medical curriculum. Medical Education, 38(5), 482-491. http://doi.org/10.1046/j.1365-2929.2004.01814.x

Niemi, P. M., \& Vainiomäki, P. T. (2006). Medical students' distress-quality, continuity and gender differences during a six-year medical programme. Medical Teacher, 28(2), $136-141$. http://dx.doi.org/10.1080/01421590600607088

Salmons, P. H. (1983). Psychiatric illness in medical students. The British Journal of Psychiatry, 143(5), $505-508$. http://dx.doi.org/10.1192/bjp.143.5.505

Sherina, M. S., Rampal, L., \& Kaneson, N. (2004). Psychological stress among undergraduate medical students. Medical Journal of Malaysia, 59(2), 207-211.

Singh, G., Hankins, M., \& Weinman, J. A. (2004). Does medical school cause health anxiety and worry in medical students? Medical Education, 38(5), 479-481. http://dx.doi.org/10.1046/j.1365-2929.2004.01813.x

Styles, W. M. (1993). Stress in undergraduate medical education:'the mask of relaxed brilliance'. Br J Gen Pract, 43(367), 46-47.

Tyssen, R., Vaglum, P., Grønvold, N. T., \& Ekeberg, Ø. (2005). The relative importance of individual and organizational factors for the prevention of job stress during internship: a nationwide and prospective study. Medical Teacher, 27(8), 726-731. http://dx.doi.org/10.1080/01421590500314561

Vitaliano, P. P., Maiuro, R. D., Mitchell, E., \& Russo, J. (1989). Perceived stress in medical school: resistors, persistors, adaptors and maladaptors. Social Science \& Medicine, 28(12), 1321-1329. http://dx.doi.org/10.1016/0277-9536(89)90351-1

Vitaliano, P. P., Russo, J., Carr, J. E., \& Heerwagen, J. H. (1984). Medical school pressures and their relationship to anxiety. The Journal of Nervous and Mental Disease, 172(12), 730-736. http://dx.doi.org/10.1097/00005053-198412000-00006

Wald, H. S., Haramati, A., Bachner, Y. G., \& Urkin, J. (2016). Promoting resiliency for interprofessional faculty and senior medical students: Outcomes of a workshop using mind-body medicine and interactive reflective writing. Medical Teacher, 1-4. http://dx.doi.org/10.3109/0142159X.2016.1150980

Wolf, T. M., Randall, H. M., \& Faucett, J. M. (1988). A survey of health promotion programs in US and Canadian medical schools. American Journal of Health Promotion, 3(1), 33-36. http://dx.doi.org/10.4278/0890-1171-3.1.33 
Appendix-1: The Higher Education Stress Inventory Questionnaire

\begin{tabular}{|c|c|c|c|c|}
\hline & $\begin{array}{l}\text { Totally } \\
\text { disagree }\end{array}$ & $\begin{array}{l}\text { Somewhat } \\
\text { disagree }\end{array}$ & $\begin{array}{l}\text { Somewhat } \\
\text { agree }\end{array}$ & $\begin{array}{l}\text { Totally } \\
\text { agree }\end{array}$ \\
\hline \multicolumn{5}{|l|}{ 1. Studies control my life \& I have little time for other activities. } \\
\hline \multicolumn{5}{|l|}{ 2. I feel that my teachers treat me with respect } \\
\hline \multicolumn{5}{|l|}{$\begin{array}{l}\text { 3. I am worried that I will not acquire all the knowledge needed } \\
\text { for my future. }\end{array}$} \\
\hline \multicolumn{5}{|l|}{$\begin{array}{l}\text { 4. The studies have created anonymity and isolation among } \\
\text { students. }\end{array}$} \\
\hline \multicolumn{5}{|l|}{ 5. The teachers often fail to clarify the aims of the studies. } \\
\hline \multicolumn{5}{|l|}{ 6. The studies stimulate my personal development. } \\
\hline \multicolumn{5}{|l|}{$\begin{array}{l}\text { 7. The professional role presented in the training conflicts with } \\
\text { my personal views. }\end{array}$} \\
\hline \multicolumn{5}{|l|}{ 8. The teachers give encouragement and personal attention. } \\
\hline \multicolumn{5}{|l|}{ 9. There is a competitive attitude among students. } \\
\hline \multicolumn{5}{|l|}{ 10. I am satisfied with my choice of career. } \\
\hline \multicolumn{5}{|l|}{$\begin{array}{l}\text { 11. I feel that the studies have played a role in creating a cold and } \\
\text { impersonal attitude among students. }\end{array}$} \\
\hline \multicolumn{5}{|l|}{ 12. As a student, my financial situation is a worry. } \\
\hline \multicolumn{5}{|l|}{ 13. My fellow students support me. } \\
\hline \multicolumn{5}{|l|}{$\begin{array}{l}\text { 14. I worry about long working hours and responsibilities in my } \\
\text { future career. }\end{array}$} \\
\hline \multicolumn{5}{|l|}{$\begin{array}{l}\text { 15. The training is characterized by an atmosphere where } \\
\text { weakness and personal shortcomings are not accepted. }\end{array}$} \\
\hline \multicolumn{5}{|l|}{$\begin{array}{l}\text { 16. As a student you are often expected to participate in } \\
\text { situations where your role and function is unclear. }\end{array}$} \\
\hline \multicolumn{5}{|l|}{ 17. I am proud of my future profession. } \\
\hline \multicolumn{5}{|l|}{$\begin{array}{l}\text { 18. The requirement for doing research is a source of worry for } \\
\text { me }\end{array}$} \\
\hline \multicolumn{5}{|l|}{ 19. I am able to influence the content and process of studies } \\
\hline \multicolumn{5}{|l|}{$\begin{array}{l}\text { 20. The insight I have had into my future profession has made me } \\
\text { worried about the stressful workload. }\end{array}$} \\
\hline \multicolumn{5}{|l|}{$\begin{array}{l}\text { 21. There is too much focus on passive learning of facts and too } \\
\text { little on active seeking of knowledge and time for reflection }\end{array}$} \\
\hline \multicolumn{5}{|l|}{$\begin{array}{l}\text { 22. Expectations from my family have influenced my choice of } \\
\text { career too much }\end{array}$} \\
\hline \multicolumn{5}{|l|}{ 23. I am worried about accommodation } \\
\hline \multicolumn{5}{|l|}{$\begin{array}{l}\text { 24. The requirement for frequent presentations is a source of } \\
\text { worry for me. }\end{array}$} \\
\hline \multicolumn{5}{|l|}{$\begin{array}{l}\text { 25. I meet many qualified doctors that seem dejected or } \\
\text { dissatisfied in their profession }\end{array}$} \\
\hline \multicolumn{5}{|l|}{$\begin{array}{l}\text { 26. I feel that the training is preparing me well for my future } \\
\text { profession }\end{array}$} \\
\hline \multicolumn{5}{|l|}{$\begin{array}{l}\text { 27. There is a sense of community which contributes to a better } \\
\text { working environment for students. }\end{array}$} \\
\hline \multicolumn{5}{|l|}{ 28. I am worried about my future financial status. } \\
\hline $\begin{array}{l}\text { 29. The education is highly characterized by group activities with } \\
\text { unclear goals and with too much responsibility placed on the } \\
\text { student. }\end{array}$ & & & & \\
\hline
\end{tabular}




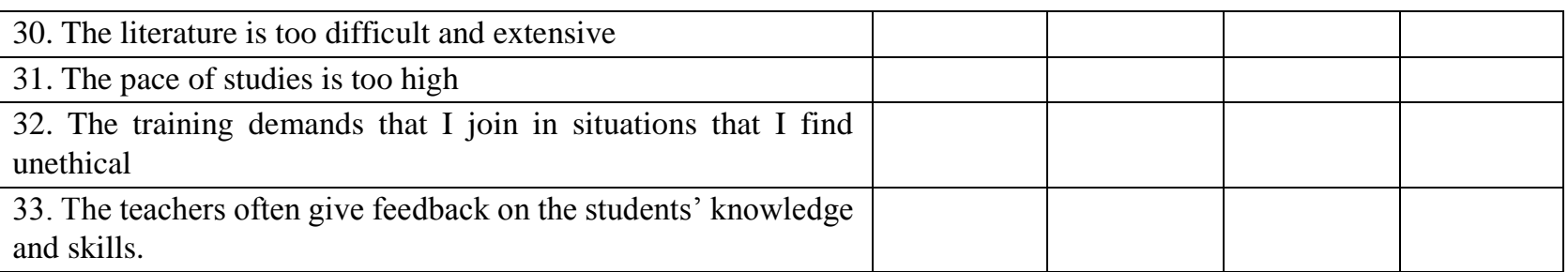

\section{Appendix-2: Factors category of the HESI}

\begin{tabular}{|c|c|}
\hline HESI Factors & Pertaining items \\
\hline $\begin{array}{lr}\text { Worries about } & \text { Future } \\
\text { Endurance/ } & \text { Capacity } \\
(\text { WFEC) } & \end{array}$ & $\begin{array}{l}\text { 3. I am worried that I will not acquire all the knowledge needed for y future } \\
\text { profession. } \\
\text { 14. I worry about long working hours and responsibilities in my future career. } \\
\text { 20. The insight I have had into my future profession has made me worried } \\
\text { about the stressful workload. }\end{array}$ \\
\hline Non-supportive climate & $\begin{array}{l}\text { 4. The studies have created anonymity and isolation among students. } \\
\text { 7. The professional role presented in the training conflicts with my personal } \\
\text { views. } \\
\text { 9. There is a competitive attitude among students. } \\
\text { 11. I feel that the studies have played a role in creating a cold and impersonal } \\
\text { attitude among students. }\end{array}$ \\
\hline Faculty shortcomings & $\begin{array}{l}\text { 2. I feel that my teachers treat me with respect. } \\
\text { 5.The teachers often fail to clarify the aims of the studies. } \\
\text { 6. The studies stimulate my personal development. } \\
\text { 16. As a student you are often expected to participate in situations where your } \\
\text { role and function is unclear. } \\
\text { 19. I am able to influence the studies } \\
\text { 21. There is too much focus on passive learning of facts and too little on active } \\
\text { seeking of knowledge and time for reflection. } \\
\text { 26. I feel that the training is preparing me well for my future profession. }\end{array}$ \\
\hline Workload & $\begin{array}{l}\text { 1.Studies control my life and I have little time for other activities } \\
\text { 30. The literature is too difficult and extensive } \\
\text { 31. The pace of studies is too high. } \\
\text { 18. the requirement of doing frequent presentation is a source of worry to me } \\
\text { 24. the requirement of doing frequent research is a source of a worry to me }\end{array}$ \\
\hline Insufficient Feedback & $\begin{array}{l}\text { 8. The teachers give encouragement and personal attention. } \\
\text { 33. The teachers often give feedback on the students' knowledge and skills }\end{array}$ \\
\hline Low commitment & $\begin{array}{l}\text { 10. I am satisfied with my choice of career. } \\
\text { 17. I am proud of my future profession. }\end{array}$ \\
\hline Financial Concerns & $\begin{array}{l}\text { 12. As a student, my financial situation is a worry } \\
\text { 28. I am worried about my future economy and my ablility to repay student } \\
\text { loans. }\end{array}$ \\
\hline
\end{tabular}

